\title{
New Sesquicillins, Insecticidal Antibiotics Produced by Albophoma sp. FKI-1778
}

\author{
Ryuji Uchida, Rie Imasato, Yuichi Yamaguchi, Rokuro Masuma, Kazuro Shiomi, \\ Hiroshi Tomoda, Satoshi Ōmura
}

Received: April 14, 2005 / Accepted: June 9, 2005

(C) Japan Antibiotics Research Association

\begin{abstract}
Four new antibiotics, sesquicillins B to E were isolated from the culture broth of Albophoma sp. FKI-1778 together with known sesquicillin (sesquicillin $\mathrm{A}$ in this paper). The structures of sesquicillins were elucidated by spectroscopic studies including various NMR experiments. All sesquicillins have a common pyrano-diterpene skeleton. Sesquicillins showed moderate inhibitory activity against the growth of Artemia salina (brine shrimps) and Jurkat cells.
\end{abstract}

Keywords sesquicillins, insecticidal, antibiotic, fungal metabolites, Albophoma sp., pyrano-diterpene skeleton

\section{Introduction}

In the course of our screening program for insecticidal antibiotics using Artemia salina (brine shrimps) as a test organism, we have reported several new antibiotics of microbial origin [1 3]. Our continuous efforts rewarded us the discovery of five structurally related antibiotics, which were isolated from the cultured broth of Albophoma sp. FKI-1778. One was identified as sesquicillin (1) (Fig. 1), previously reported to show a variety of biological activities such as antihypertensive, bronchoapasmolytic, anti-inflammatory, laxative activities, anti-cancer, glucocorticoid mediated signal transduction inhibitor and G1 phase arrest [4 7]. But four others were found to be

H. Tomoda (Corresponding author), K. Shiomi: School of Pharmaceutical Sciences, Kitasato University, 5-9-1 Shirokane, Minato-ku, Tokyo 108-8641, Japan, E-mail: tomoda@lisci. kitasato-u.ac.jp

R. Uchida, R. Imasato, Y. Yamaguchi, R. Masuma, S. Ōmura: new compounds. Therefore, known sesquicillin was renamed sesquicillin $\mathrm{A}$, and new ones were designated<smiles>[R]C[C@]1(C)CC[C@@H](OC(C)=O)[C@H](C)[C@@H]1CCC(=C)Cc1c(O)c(C)c(C)oc1=O</smiles>

\begin{tabular}{|c|c|}
\hline Sesquicillin & $\mathrm{R}$ \\
\hline $\begin{array}{c}\mathrm{A}(\mathbf{1}) \\
\text { (Sesquicillin) }\end{array}$ & \\
\hline B (2) & \\
\hline $\mathrm{C}(\mathbf{3})$ & \\
\hline D (4) & \\
\hline $\mathrm{E}(\mathbf{5})$ & \\
\hline
\end{tabular}

Fig. 1 Structures of sesquicillins.
The Kitasato Institute, 5-9-1 Shirokane, Minato-ku, Tokyo 1088641, Japan, and Kitasato Institute for Life Sciences, \& Graduate School of Infection Control Sciences, Kitasato University, 5-9-1 Shirokane, Minato-ku, Tokyo 108-8641, Japan 
sesquicillins B (2) to E (5) (Fig. 1). In this paper, the taxonomy of the producing fungus, fermentation, isolation, structure elucidation and biological properties of sesquicillins are described.

\section{Materials and Methods}

\section{General}

NMR spectra were recorded on a Varian Inova 600 spectrometer $\left({ }^{2-3} J_{\mathrm{CH}}=8 \mathrm{~Hz}\right.$ in $\left.\mathrm{HMBC}\right)$. Chemical shifts are shown in $\delta$ values (ppm) relative to methanol- $d_{4}$ at $3.31 \mathrm{ppm}$ for ${ }^{1} \mathrm{H}$ NMR and at $49.0 \mathrm{ppm}$ for ${ }^{13} \mathrm{C}$ NMR. FAB mass spectrometry was conducted on a JEOL JMSAX505H spectrometer. UV and IR spectra were measured with a Beckman DU640 spectrophotometer and a Horiba FT-210 Fourier transform infrared spectrometer, respectively. Optical rotations were recorded on a JASCO model DIP-181 polarimeter.

\section{Taxonomic Studies of the Producing Fungus}

The fungal strain FKI-1778 was isolated from a soil sample collected at Amamiooshima Island, Kagoshima Prefecture, Japan. Morphological observations were done under the microscopes (Olympus Vanox-S AH-2 and Olympus SZH10). Color hues were described according to Color Harmony Manual, 4th Ed [8]. For the taxonomic studies of the fungus, potato dextrose agar (PDA, Difco), cornmeal agar (CMA), malt extract agar (MEA), Miura's medium (LCA) were used.

\section{Fermentation}

For production of sesquicillins, a seed medium contained glucose $2.0 \%$, yeast extract (Oriental Yeast Co.) $0.2 \%$, $\mathrm{MgSO}_{4} \cdot 7 \mathrm{H}_{2} \mathrm{O} \quad 0.05 \%$, Polypepton (Daigo Nutritive Chemicals) $0.5 \%, \mathrm{KH}_{3} \mathrm{PO}_{4} 0.1 \%$ and agar $0.1 \%$. The $\mathrm{pH}$ was adjusted to 6.0 prior to sterilization. The production medium was composed of glycerol $3.0 \%$, oat meal $2.0 \%$, dry yeast $1.0 \%, \mathrm{KH}_{2} \mathrm{PO}_{4} \quad 1.0 \%, \mathrm{Na}_{2} \mathrm{HPO}_{4} \quad 1.0 \%$ and $\mathrm{MgSO}_{4} \cdot 7 \mathrm{H}_{2} \mathrm{O} 0.05 \%$. The $\mathrm{pH}$ was not adjusted prior to sterilization. A stock culture of strain Albophoma sp. FKI1778 was inoculated into a 500-ml Erlenmeyer flask containing $100 \mathrm{ml}$ of the seed medium and incubated on a rotary shaker at $27^{\circ} \mathrm{C}$ for 2 days. The main culture was initiated by transferring $1 \mathrm{ml}$ of the seed culture into a 500 $\mathrm{ml}$ Erlenmeyer flask containing $100 \mathrm{ml}$ of the production medium, and the fermentation was carried out at $27^{\circ} \mathrm{C}$ with a rotary shaker at $210 \mathrm{rpm}$.

\section{Quantitative Analysis of Sesquicillins by HPLC}

The amount of sesquicillins was measured by analytical
HPLC (HP1100, Hewlett-Packard). Samples dissolved in methanol were analyzed under the following conditions: column, Symmetry C18/3.5 $\mu \mathrm{m}(2.1 \times 150 \mathrm{~mm}$, Waters $)$; mobile phase, a 20-minute linear gradient from $30 \%$ $\mathrm{CH}_{3} \mathrm{CN} / 0.05 \% \mathrm{H}_{3} \mathrm{PO}_{4}$ to $70 \% \mathrm{CH}_{3} \mathrm{CN} / 0.05 \% \mathrm{H}_{3} \mathrm{PO}_{4}$; flow rate, $0.2 \mathrm{ml} /$ minute; detection, $\mathrm{UV}$ at $240 \mathrm{~nm}$. Compounds 1 through 5 eluted at retention times of 12.4, 4.9, 5.6, 6.1 and 6.9 minutes, respectively.

\section{Insecticidal Activity}

Insecticidal activity was assayed by a microtiter-plate assay using brine shrimps, A. salina (Pfizer Consumer Inc) as reported previously [1]. Briefly, about 10 nauplii larvae hatched from eggs of brine shrimps were incubated in a well of 96-well microplates at room temperature with test samples. After 48 hours, the motilities were assessed visually in comparison with controls (no samples).

\section{Antimicrobial Activity}

Antimicrobial activity against 14 species of microorganisms was measured by a paper disk method. Media for microorganisms are as follows: GAM agar (Nissui Seiyaku Co.) for Bacteroides fragilis; Waksman agar for Mycobacterium smegmatis; Bacto PPLO agar (Difco) supplemented with horse serum $15 \%$, glucose $0.1 \%$, phenol red $(5 \mathrm{mg} / \mathrm{ml}) \quad 0.2 \%$ and agar $1.5 \%$ for Acholeplasma laidlawii; nutrient agar for Bacillus subtilis, Staphylococcus aureus, Micrococcus luteus, Escherichia coli, Pseudomonas aeruginosa and Xanthomonas oryzae; a medium composed of glucose $1.0 \%$, yeast extract $0.5 \%$, and agar $0.8 \%$ for Pyricularia oryzae, Aspergillus niger, Mucor racemosus, Candida albicans and Saccharomyces cerevisiae. A paper disk (i.d. $6 \mathrm{~mm}$, Advantec) containing $10 \mu \mathrm{g}$ of a sample was placed on the agar plate. Bacteria, except $X$. oryzae, were incubated at $37^{\circ} \mathrm{C}$ for 24 hours. Yeasts and $X$. oryzae were incubated at $27^{\circ} \mathrm{C}$ for 24 hours. Fungi were incubated at $27^{\circ} \mathrm{C}$ for 48 hours. Antimicrobial activity was expressed as diameter $(\mathrm{mm})$ of inhibitory zone.

\section{Cytotoxic Activity}

Jurkat cells, from a human $\mathrm{T}$ cell leukemia, were cultured in RPMI-1640 medium supplemented with $10 \%$ fetal bovine serum, 100 units $/ \mathrm{ml}$ penicillin and $100 \mu \mathrm{g} / \mathrm{ml}$ streptomycin in a humidified chamber at $37^{\circ} \mathrm{C}$ containing $5 \% \mathrm{CO}_{2}$. Cell growth was measured by the colorimetric 3(4,5-dimethylthiazo-2-yl)-2,5-diphenyl-tetrazolium bromide (MTT) colorimetric assay [9]. Jurkat cells $\left(5 \times 10^{4}\right.$ cells in $50 \mu \mathrm{l}$ per well) in 96-well microplates and $50 \mu \mathrm{l}$ of various concentrations of sesquicillins were added to each well and incubated for 24 hours at $37^{\circ} \mathrm{C}$. MTT $(10 \mu \mathrm{l}$ of $5.5 \mathrm{mg} / \mathrm{ml}$ stock solution, SIGMA) and $90 \mu \mathrm{l}$ of cell lysate 


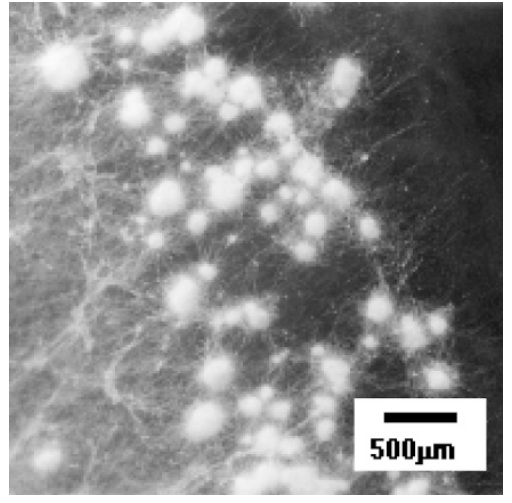

Fig. 2 Photomicrograph of pycnidia of strain FKI-1778.

solution $(40 \% \mathrm{~N}$, N-dimethylformamide, $20 \%$ sodium dodecyl sulfate, $2 \% \mathrm{CH}_{3} \mathrm{COOH}, 0.03 \% \mathrm{HCl}$ ) was added and the plate was shaken for 1 hour. The optical density of each well was measured at $540 \mathrm{~nm}$ using a microtiter-plate reader (Elx 808, Bio-Tek Instruments, Inc.).

\section{Results}

\section{Taxonomy of the Producing Fungus}

Colonies on PDA were $72 \sim 74 \mathrm{~mm}$ in diameter after 14 days at $25^{\circ} \mathrm{C}$, floccose, corrugate, white (a) in color with moderately pycnidia formation; reverse was cream (1 $1 / 2$ ca). Colonies on CMA were $70 \sim 71 \mathrm{~mm}$ in diameter after 14 days at $25^{\circ} \mathrm{C}$, floccose, white (a) to cream $\left(\begin{array}{lll}1 & 1 / 2 & \mathrm{ca}\end{array}\right)$ with moderately pycnidia formation. Colonies on MEA were $72 \sim 73 \mathrm{~mm}$ in diameter after 14 days at $25^{\circ} \mathrm{C}$, floccose, pulvinate in the center and, white (a) to cream (1 $1 / 2 \mathrm{ca}$ ) in color with poor pycnidia formation; reverse was light ivory $(2 \mathrm{ca}$ ). Colonies on LcA were $50 \sim 60 \mathrm{~mm}$ in diameter after 14 days at $25^{\circ} \mathrm{C}$, floccose, white (a) with moderately pycnidia formation. Pycnidia were pure white, epibiotic, globose to subglobose, often gregarious, and $100 \sim 300 \mu \mathrm{m}$ in size. Pycnidial wall was thin, fleshy and soft, and prosenchymatous (Fig. 2). Conidiophores were arising from inner hyphae of pycnidium, producing conidia holoblastically. Conidia were unicellular, hyaline, globose, and $1.6 \sim 2.2 \mu \mathrm{m}$ in size.

From the above characteristics, strain FKI-1778 was considered to belong to the genus Albophoma [10] and named it Albophoma sp. FKI-1778. The strain was deposited to the National Institute of Bioscience and Human-Technology, Agency of Industrial Science and Technology Japan, as FERM BP-08668.

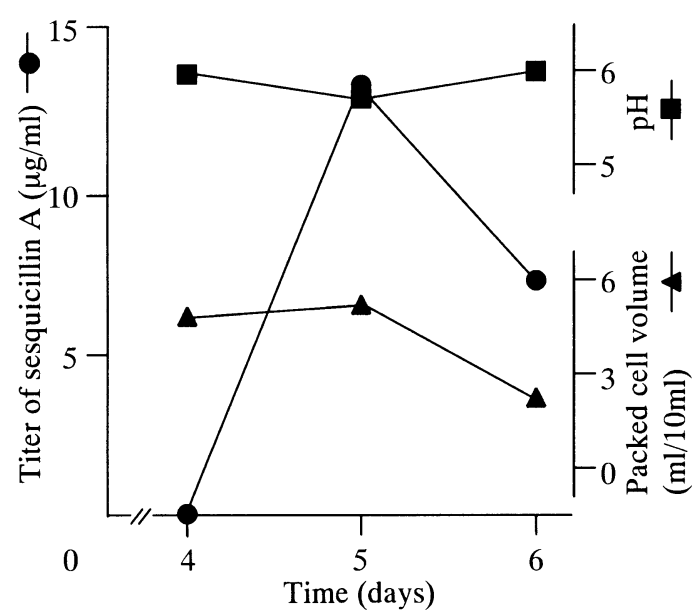

Fig. 3 A typical time course of sesquicillin production by Albophoma sp. FKI-1778.

\section{Fermentation}

A typical time course of the sesquicillin production is shown in Fig. 3. Sesquicillin A was not detected in the culture until day 4 , but the concentration reached a maximal level $(13 \mu \mathrm{g} / \mathrm{ml})$ on day five.

\section{Isolation}

The isolation procedure for sesquicillins is summarized in Fig. 4. The 168-hour old culture broth (6 liters) was centrifuged to obtain the supernatant which was extracted with an equal volume of ethyl acetate. The organic layer was dried over $\mathrm{Na}_{2} \mathrm{SO}_{4}$ and concentrated under reduced pressure to give a dark brown oil $(814 \mathrm{mg})$. After dissolving with $\mathrm{MeOH}$, the soluble fraction was applied to centrifugal partition chromatography (Sanki Engineering Ltd.). The lower phase of the solvent was introduced by ascending method. The active fractions were eluted with the upper phase to give two fractions (Fr. 1 and 2) and concentrated under reduced pressure. Fr. 1 (90.3 mg) containing 2 through $\mathbf{5}$ was subjected to preparative HPLC. Compounds $\mathbf{2}$ through $\mathbf{5}$ eluted at retention times of 21.8, 25.3, 28.7 and 37.2 minutes, respectively. Each collected fraction was concentrated to dryness to give pure $\mathbf{2}$ ( $4.4 \mathrm{mg}), \mathbf{3}$ (18.6 $\mathrm{mg}), \mathbf{4}(2.5 \mathrm{mg})$ and $\mathbf{5}(3.9 \mathrm{mg})$ as a pale yellow powder. Fr. $2(70.4 \mathrm{mg})$ containing 1 was subjected to preparative HPLC. Compound 1 eluted at retention time of 57 minutes. The collected fraction was concentrated to dryness to give pure $\mathbf{1}(4.6 \mathrm{mg})$, as a pale yellow powder.

\section{Structure Elucidation}

The physico-chemical properties of $\mathbf{1}$ to $\mathbf{5}$ are summarized in Table 1. The molecular formulas of $\mathbf{2}$ to $\mathbf{5}$ were revealed to be $\mathrm{C}_{29} \mathrm{H}_{40} \mathrm{O}_{7}, \mathrm{C}_{29} \mathrm{H}_{42} \mathrm{O}_{6}, \mathrm{C}_{29} \mathrm{H}_{42} \mathrm{O}_{6}$ and $\mathrm{C}_{29} \mathrm{H}_{42} \mathrm{O}_{6}$ by HR- 


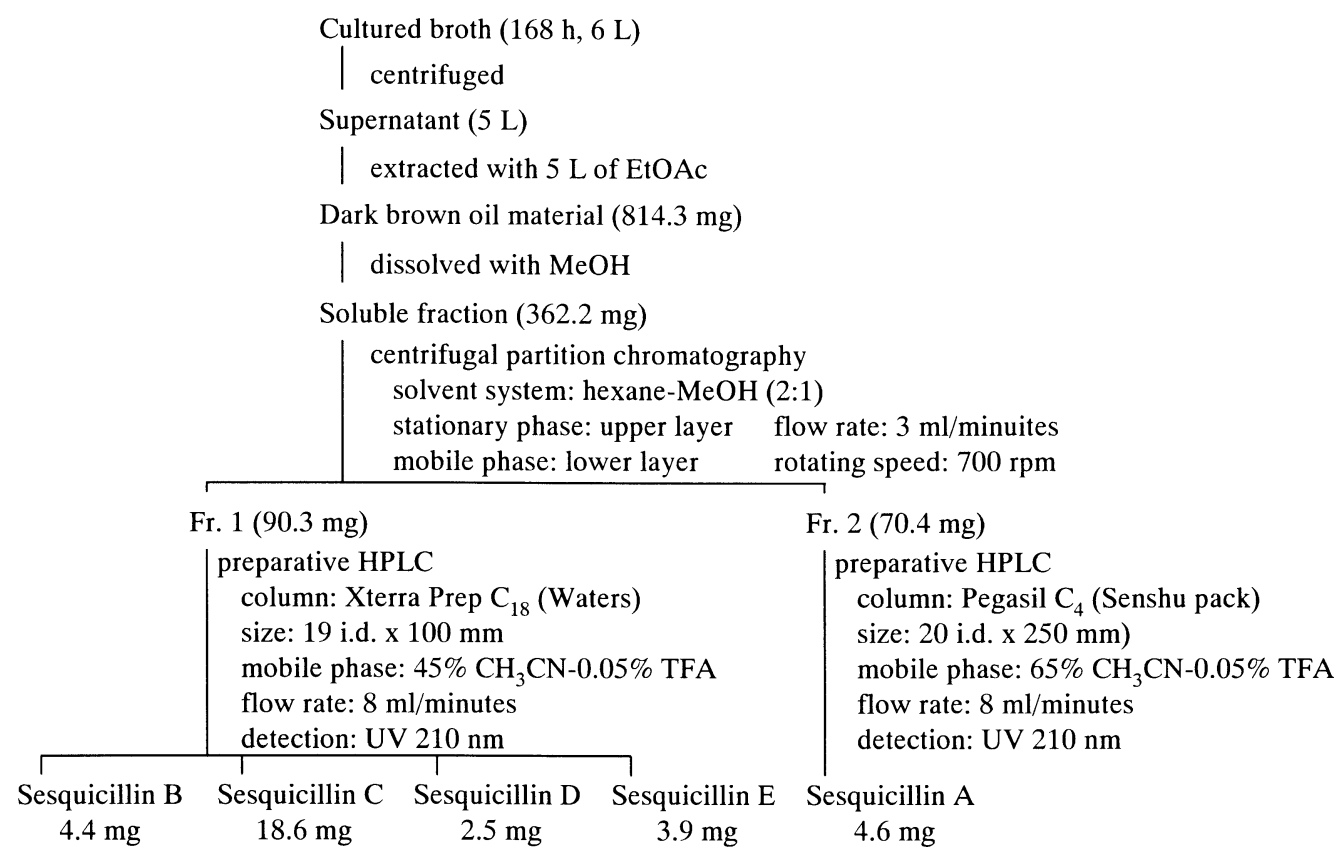

Fig. 4 Purification procedure of sesquicillins from the culture broth of Albophoma sp. FKI-1778.

Table 1 Physico-chemical properties of $\mathbf{1}$ to $\mathbf{5}$

\begin{tabular}{|c|c|c|c|c|c|}
\hline & 1 & 2 & 3 & 4 & 5 \\
\hline Appearance & Pale yellow powder & Pale yellow powder & Pale yellow powder & Pale yellow powder & Pale yellow powder \\
\hline Molecular weight & 470 & 500 & 486 & 486 & 486 \\
\hline \multicolumn{6}{|l|}{ HRFAB-MS } \\
\hline calcd & $470.3032\left[\mathrm{IM}^{+}\right.$ & $523.2672(\mathrm{M}+\mathrm{Na})^{+}$ & $509.2879(\mathrm{M}+\mathrm{Na})^{+}$ & $509.2879(\mathrm{M}+\mathrm{Na})^{+}$ & $509.2879(\mathrm{M}+\mathrm{Na})^{+}$ \\
\hline found & $470.3055[\mathrm{M}]^{+}$ & $523.2705(\mathrm{M}+\mathrm{Na})^{+}$ & $509.2899(\mathrm{M}+\mathrm{Na})^{+}$ & $509.2857(\mathrm{M}+\mathrm{Na})^{+}$ & $509.2885(\mathrm{M}+\mathrm{Na})^{+}$ \\
\hline $\begin{array}{l}\text { UV } \lambda_{\max } \mathrm{nm}(\varepsilon) \\
\quad \text { in } \mathrm{MeOH}\end{array}$ & $290(10,900)$ & $294(9,300)$ & $297(6,100)$ & $293(7,800)$ & $295(6,500)$ \\
\hline $\mathrm{IR} \varpi_{\max } \mathrm{cm}^{-1}(\mathrm{KBr})$ & $\begin{array}{l}3425,2930,1735 \\
1606,1670,1560 \\
1450,1385,1240 \\
1115,1075,1030\end{array}$ & $\begin{array}{l}3430,2960,1687 \\
1564,1450,1390 \\
1259,1097,1036 \\
806\end{array}$ & $\begin{array}{l}3430,2938,2360 \\
1725,1673,1563 \\
1448,1388,1247 \\
1146,1028,887\end{array}$ & $\begin{array}{l}3430,2940,2327 \\
1678,1558,1461 \\
1390,1254,1081 \\
1037,808\end{array}$ & $\begin{array}{l}3430,2933,2358, \\
1677,1563,1450 \\
1388,1257,1197, \\
1085,1033,806\end{array}$ \\
\hline$[\alpha]_{D}\left(23^{\circ} \mathrm{C}\right)$ & $\begin{array}{c}-18.0^{\circ} \\
(c 0.1, \mathrm{MeOH})\end{array}$ & $\begin{array}{c}-27.4^{\circ} \\
\text { (c } 0.1, \mathrm{MeOH})\end{array}$ & $\begin{array}{c}-59.0^{\circ} \\
(c 0.1, \mathrm{MeOH})\end{array}$ & $\begin{array}{c}-27.3^{\circ} \\
(c 0.1, \mathrm{MeOH})\end{array}$ & $\begin{array}{c}-34.9^{\circ} \\
(c 0.1, \mathrm{MeOH})\end{array}$ \\
\hline \multicolumn{6}{|l|}{ Solubility } \\
\hline soluble & $\begin{array}{c}\mathrm{CHCl}_{3}, \mathrm{MeOH}, \\
\mathrm{DMSO}\end{array}$ & $\begin{array}{c}\mathrm{CHCl}_{3}, \mathrm{MeOH}, \\
\mathrm{DMSO}\end{array}$ & $\begin{array}{c}\mathrm{CHCl}_{3}, \mathrm{MeOH}, \\
\text { DMSO }\end{array}$ & $\begin{array}{c}\mathrm{CHCl}_{3}, \mathrm{MeOH}, \\
\mathrm{DMSO}\end{array}$ & $\begin{array}{c}\mathrm{CHCl}_{3}, \mathrm{MeOH} \\
\text { DMSO }\end{array}$ \\
\hline insoluble & Hexane, $\mathrm{H}_{2} \mathrm{O}$ & Hexane, $\mathrm{H}_{2} \mathrm{O}$ & Hexane, $\mathrm{H}_{2} \mathrm{O}$ & Hexane, $\mathrm{H}_{2} \mathrm{O}$ & Hexane, $\mathrm{H}_{2} \mathrm{O}$ \\
\hline
\end{tabular}

FAB-MS, respectively. Similarity in physico-chemical properties strongly suggested that they are structurally related.

MS data and ${ }^{1} \mathrm{H}$ and ${ }^{13} \mathrm{C}$ NMR analysis identified $\mathbf{1}$ as sesquicillin $\mathrm{A}$, which was previously isolated from a fungus. Generally, the structures of $\mathbf{2}$ to $\mathbf{5}$ were elucidated by extensive NMR experiments in $\mathrm{CD}_{3} \mathrm{OD}$. The assignment of the ${ }^{1} \mathrm{H}$ and ${ }^{13} \mathrm{C}$ NMR signals was facilitated by ${ }^{1} \mathrm{H}-{ }^{1} \mathrm{H}$ COSY and HMQC experiments (Table 2). The carbon skeleton and the relative stereochemistry were demonstrated by HMBC and NOE experiments (pertinent HMBC and NOESY correlations are shown in Fig. 5). A 


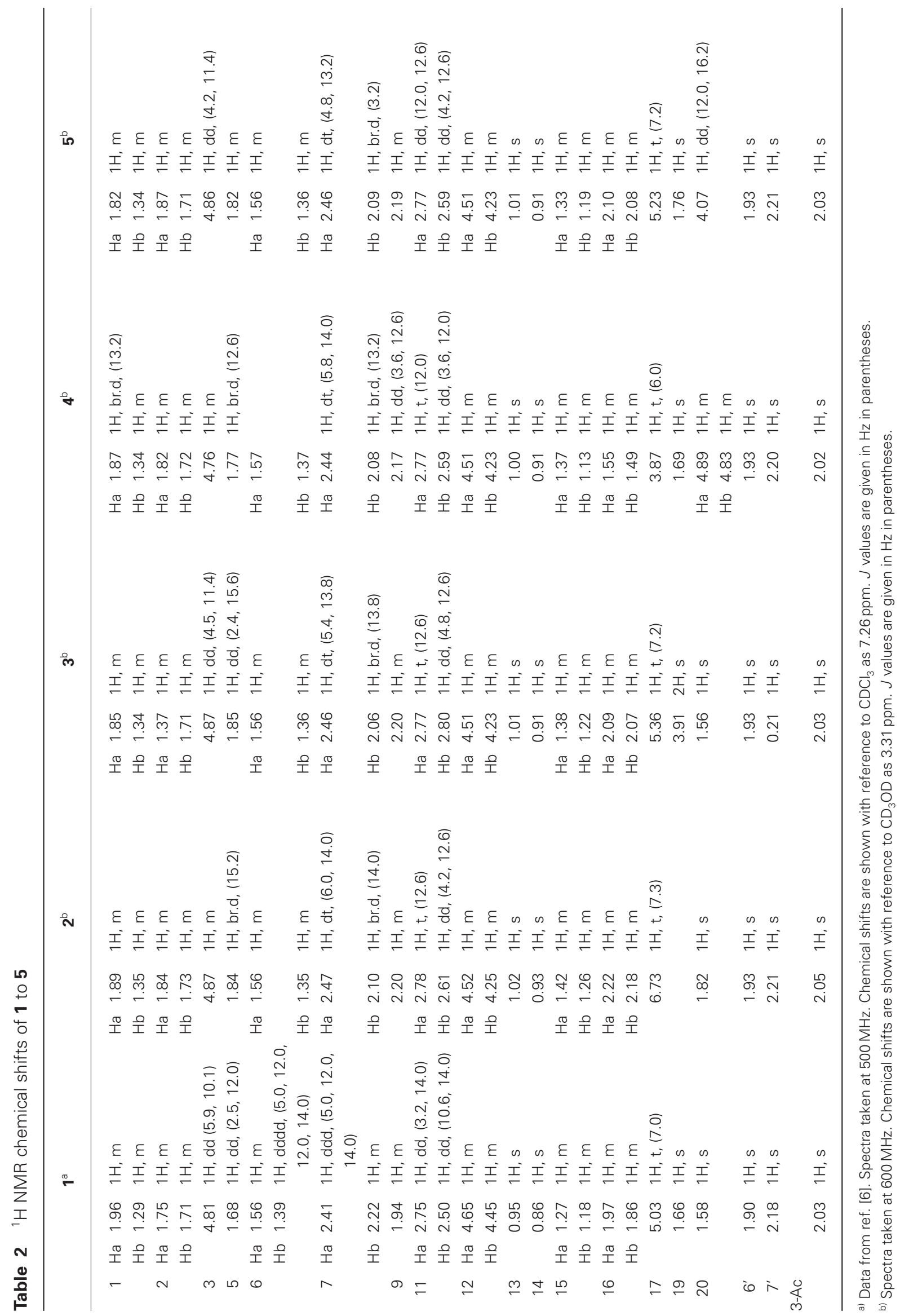




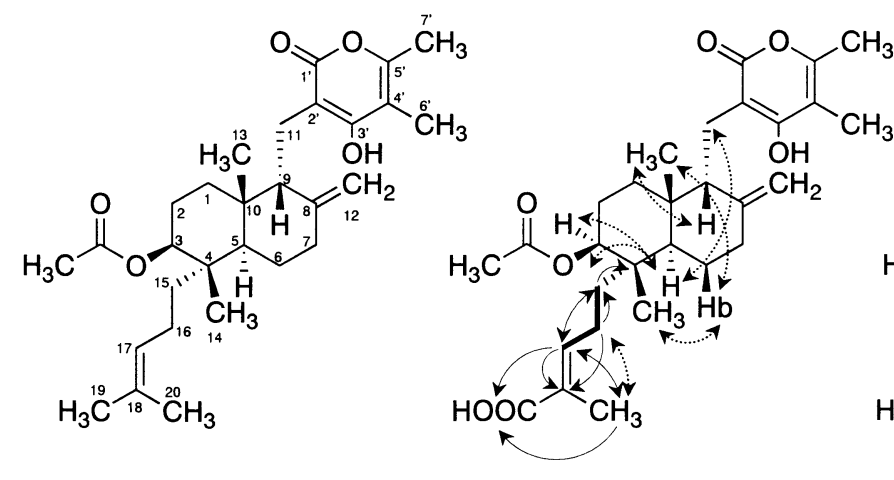

Sesquicillin A (1)

Sesquicillin B (2)

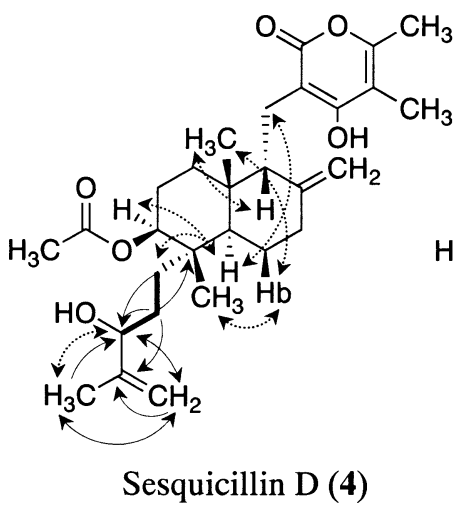

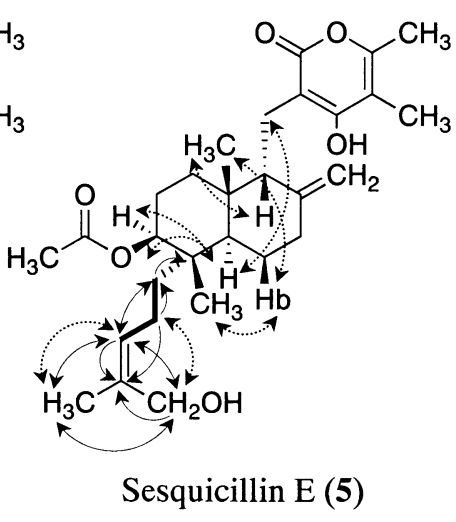

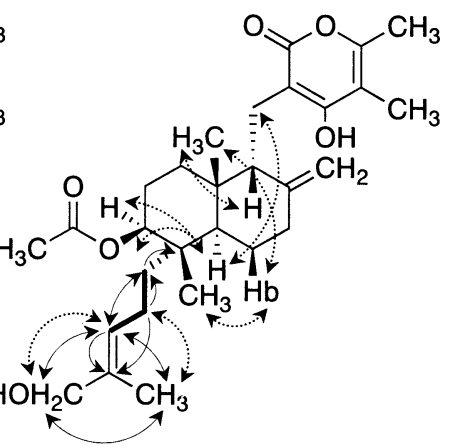

Sesquicillin C (3)

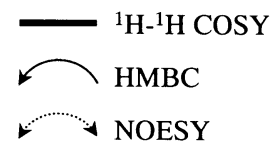

Fig. $5 \quad{ }^{1} \mathrm{H}-{ }^{1} \mathrm{H}$ COSY, HMBC and NOESY experiments for sesquicillins.

comparison of ${ }^{1} \mathrm{H}$ and ${ }^{13} \mathrm{C}$ NMR data of $\mathbf{2}$ to $\mathbf{5}$ with those of 1 indicated the presence of pyrano-diterpenoid moiety, in common.

Structure of 2: The ${ }^{1} \mathrm{H}$ and ${ }^{13} \mathrm{C}$ NMR spectra (Tables 2 and 3 ) resembled those of 1 except for the proton and carbon signals of C-17, C-18, C-19 and C-20. The ${ }^{13} \mathrm{C}-{ }^{1} \mathrm{H}$ long-range couplings of ${ }^{2} J$ and ${ }^{3} J$ in the $\mathrm{HMBC}$ experiments are shown in Fig. 5, giving the following results. The cross peaks from $16-\mathrm{H}^{2}(\delta 2.18,2.22)$ to $s p^{2}$ quaternary carbon $\mathrm{C}-18(\delta 128.7)$, from $17-\mathrm{H}(\delta 6.73)$ to C-18, carboxy carbon C-19 $(\delta 171.6)$ and methyl carbon C$20(\delta 12.3)$ and from $20-\mathrm{H} 3(\delta 1.82)$ to $s p^{2}$ methine carbon $\mathrm{C}-17(\delta 143.7)$ and $\mathrm{C}-19$ indicated that 2 has a carboxy group instead of the methyl group (C-19) of $\mathbf{1}$. The NOESY spectrum of $\mathbf{2}$ had the cross peaks between $16-\mathrm{H}_{2}$ and $20-\mathrm{H}_{3}$, but not between $17-\mathrm{H}_{2}$ and $20-\mathrm{H}_{3}$, indicating that the double bond between $\mathrm{C}-17$ and $\mathrm{C}-18$ is the $E$ isomer.

Structure of 3: The ${ }^{1} \mathrm{H}$ and ${ }^{13} \mathrm{C}$ NMR spectra (Tables 2 and 3 ) also resembled those of $\mathbf{1}$ except for the proton and carbon signals of C-19. In the HMBC experiments (Fig. 5), the cross peaks from oxymethylene proton $19-\mathrm{H}_{2}\left(\begin{array}{l}\delta \\ \delta\end{array} .91\right)$ to $s p^{2}$ methine carbon $\mathrm{C}-17$ ( $\delta$ 126.8), $s p^{2}$ quaternary carbon $\mathrm{C}-18(\delta$ 135.9) and methyl carbon C-20 ( $\delta$ 17.5) indicated that $\mathbf{3}$ has a hydroxymethyl residue at C-19 instead of the methyl group of $\mathbf{1}$. The NOESY spectrum of 3 had the cross peaks between $16-\mathrm{H}_{2}$ and $20-\mathrm{H}_{3}$ and between $17-\mathrm{H}$ and $19-\mathrm{H}_{2}$, indicating that the double bond between $\mathrm{C}-17$ and $\mathrm{C}-18$ is the $E$ isomer.

Structure of 4: The ${ }^{1} \mathrm{H}$ and ${ }^{13} \mathrm{C}$ NMR spectra (Tables 2 and 3) also resembled those of $\mathbf{1}$ except for the proton and carbon signals of $\mathrm{C}-17, \mathrm{C}-18, \mathrm{C}-19$ and $\mathrm{C}-20$. The ${ }^{13} \mathrm{C}-{ }^{1} \mathrm{H}$ long-range couplings of ${ }^{2} J$ and ${ }^{3} J$ in the $\mathrm{HMBC}$ experiments are also shown in Fig. 5, giving the following results. The cross peaks from the methylene proton $16-\mathrm{H}_{2}$ $(\delta 1.49,1.55)$ to oxymethine carbon $\mathrm{C}-17(\delta 77.8)$ and $s p^{2}$ quaternary carbon $\mathrm{C}-18(\delta 144.8)$, from oxymethine proton $17-\mathrm{H}(\delta 3.87)$ to methylene carbon $\mathrm{C}-16(\delta 29.3)$ and exomethylene carbon C-20 ( $\delta$ 111.9), from methyl proton 19$\mathrm{H}_{3}(\delta 1.69)$ to $\mathrm{C}-17$ and $\mathrm{C}-18$ and from exo-methylene proton $20-\mathrm{H}_{2}(\delta 4.83,4.89)$ to $\mathrm{C}-17, \mathrm{C}-18$ and $\mathrm{C}-19$, indicated that the 3-methyl-but-3-en-2-ol residue is connected to C-16.

Structure of 5: The ${ }^{1} \mathrm{H}$ and ${ }^{13} \mathrm{C}$ NMR spectra (Tables 2 and 3 ) also resembled those of $\mathbf{3}$ except for the proton and carbon signals of C-16, C-19 and C-20. From these data, the planner structure was presumed to be the same as $\mathbf{3}$. In the HMBC experiments, the cross peaks from 
Table $3{ }^{13} \mathrm{C}$ NMR chemical shifts of $\mathbf{1}$ to $\mathbf{5}$

\begin{tabular}{rrrrrr}
\hline Position & $\mathbf{1}^{\mathrm{a}}$ & $\mathbf{2}^{\mathrm{b}}$ & $\mathbf{3}^{\mathrm{b}}$ & $\mathbf{4}^{\mathrm{b}}$ & $\mathbf{5}^{\mathrm{b}}$ \\
\hline 1 & $33.8 \mathrm{t}$ & $35.0 \mathrm{t}$ & $35.0 \mathrm{t}$ & $35.0 \mathrm{t}$ & $35.0 \mathrm{t}$ \\
\hline 2 & $24.0 \mathrm{t}$ & $25.1 \mathrm{t}$ & $25.1 \mathrm{t}$ & $25.1 \mathrm{t}$ & $25.1 \mathrm{t}$ \\
3 & $76.2 \mathrm{~d}$ & $77.3 \mathrm{~d}$ & $77.5 \mathrm{~d}$ & $77.7 \mathrm{~d}$ & $77.5 \mathrm{~d}$ \\
4 & $40.0 \mathrm{~s}$ & $41.3 \mathrm{~s}$ & $41.2 \mathrm{~s}$ & $41.5 \mathrm{~s}$ & $41.2 \mathrm{~s}$ \\
5 & $39.3 \mathrm{~d}$ & $40.4 \mathrm{~d}$ & $40.4 \mathrm{~d}$ & $40.6 \mathrm{~d}$ & $40.4 \mathrm{~d}$ \\
6 & $22.6 \mathrm{t}$ & $23.8 \mathrm{t}$ & $23.8 \mathrm{t}$ & $23.8 \mathrm{t}$ & $23.8 \mathrm{t}$ \\
7 & $30.9 \mathrm{t}$ & $32.1 \mathrm{t}$ & $32.1 \mathrm{t}$ & $32.1 \mathrm{t}$ & $32.1 \mathrm{t}$ \\
8 & $149.0 \mathrm{~s}$ & $149.7 \mathrm{~s}$ & $149.9 \mathrm{~s}$ & $150.0 \mathrm{~s}$ & $149.9 \mathrm{~s}$ \\
9 & $56.5 \mathrm{~d}$ & $56.2 \mathrm{~d}$ & $56.2 \mathrm{~d}$ & $56.2 \mathrm{~d}$ & $56.2 \mathrm{~d}$ \\
10 & $37.6 \mathrm{~s}$ & $38.6 \mathrm{~s}$ & $38.6 \mathrm{~s}$ & $38.6 \mathrm{~s}$ & $38.6 \mathrm{~s}$ \\
11 & $22.2 \mathrm{t}$ & $22.6 \mathrm{t}$ & $22.4 \mathrm{t}$ & $22.5 \mathrm{t}$ & $22.4 \mathrm{t}$ \\
12 & $111.0 \mathrm{t}$ & $110.6 \mathrm{t}$ & $110.6 \mathrm{t}$ & $110.6 \mathrm{t}$ & $110.6 \mathrm{t}$ \\
13 & $22.8 \mathrm{q}$ & $23.6 \mathrm{q}$ & $23.6 \mathrm{q}$ & $23.7 \mathrm{q}$ & $23.6 \mathrm{q}$ \\
14 & $18.0 \mathrm{q}$ & $18.6 \mathrm{q}$ & $18.7 \mathrm{q}$ & $18.8 \mathrm{q}$ & $18.7 \mathrm{q}$ \\
15 & $37.8 \mathrm{t}$ & $37.2 \mathrm{t}$ & $38.5 \mathrm{t}$ & $35.1 \mathrm{t}$ & $38.5 \mathrm{t}$ \\
16 & $21.8 \mathrm{t}$ & $23.5 \mathrm{t}$ & $22.5 \mathrm{t}$ & $29.3 \mathrm{t}$ & $21.8 \mathrm{t}$ \\
17 & $124.4 \mathrm{~d}$ & $143.7 \mathrm{~d}$ & $126.8 \mathrm{~d}$ & $77.8 \mathrm{~d}$ & $127.5 \mathrm{~d}$ \\
18 & $131.4 \mathrm{~s}$ & $128.7 \mathrm{~s}$ & $135.9 \mathrm{~s}$ & $148.8 \mathrm{~s}$ & $134.4 \mathrm{~s}$ \\
19 & $25.7 \mathrm{q}$ & $171.6 \mathrm{~s}$ & $69.0 \mathrm{t}$ & $17.5 \mathrm{q}$ & $20.3 \mathrm{q}$ \\
20 & $17.5 \mathrm{q}$ & $12.3 \mathrm{q}$ & $13.6 \mathrm{q}$ & $111.9 \mathrm{t}$ & $60.0 \mathrm{t}$ \\
$1^{\prime}$ & $165.0 \mathrm{~s}$ & $168.1 \mathrm{~s}$ & $168.1 \mathrm{~s}$ & $168.4 \mathrm{~s}$ & $168.1 \mathrm{~s}$ \\
$2^{\prime}$ & $103.0 \mathrm{~s}$ & $104.0 \mathrm{~s}$ & $104.0 \mathrm{~s}$ & $104.1 \mathrm{~s}$ & $104.0 \mathrm{~s}$ \\
$3^{\prime}$ & $164.3 \mathrm{~s}$ & $167.7 \mathrm{~s}$ & $167.7 \mathrm{~s}$ & $167.9 \mathrm{~s}$ & $167.7 \mathrm{~s}$ \\
$4^{\prime}$ & $106.0 \mathrm{~s}$ & $108.7 \mathrm{~s}$ & $108.7 \mathrm{~s}$ & $108.7 \mathrm{~s}$ & $108.7 \mathrm{~s}$ \\
$5^{\prime}$ & $155.7 \mathrm{~s}$ & $156.9 \mathrm{~s}$ & $156.9 \mathrm{~s}$ & $157.0 \mathrm{~s}$ & $156.9 \mathrm{~s}$ \\
$6^{\prime}$ & $9.9 \mathrm{q}$ & $10.4 \mathrm{q}$ & $10.4 \mathrm{q}$ & $10.4 \mathrm{q}$ & $10.4 \mathrm{q}$ \\
$7^{\prime}$ & $17.2 \mathrm{q}$ & $17.2 \mathrm{q}$ & $17.2 \mathrm{q}$ & $17.2 \mathrm{q}$ & $17.2 \mathrm{q}$ \\
$3-A c$ & $170.7 \mathrm{~s}$ & $172.6 \mathrm{~s}$ & $172.6 \mathrm{~s}$ & $172.7 \mathrm{~s}$ & $172.6 \mathrm{~s}$ \\
& $21.2 \mathrm{q}$ & $21.1 \mathrm{q}$ & $21.1 \mathrm{q}$ & $21.1 \mathrm{q}$ & $21.1 \mathrm{q}$ \\
\hline
\end{tabular}

a) Data from ref. [6]. Spectra taken at $125 \mathrm{MHz}$. Chemical shifts are shown with reference to $\mathrm{CDCl}_{3}$ as $77.0 \mathrm{ppm}$.

b) Spectra taken at $150 \mathrm{MHz}$. Chemical shifts are shown with reference to $\mathrm{CD}_{3} \mathrm{OD}$ as $49.0 \mathrm{ppm}$.

oxymethylene proton $20-\mathrm{H}_{2}(\delta 4.06,4.09)$ to $s p^{2}$ methine carbon $\mathrm{C}-17\left(\delta\right.$ 127.5), $s p^{2}$ quaternary carbon C-18 $(\delta$ $134.4)$ and methyl carbon $C-19(\delta 20.3)$ indicated that 5 has an hydroxymethyl residue instead of the methyl group C-20 of $\mathbf{1}$. The NOESY spectrum of $\mathbf{5}$ had the cross peaks between $16-\mathrm{H}_{2}$ and $20-\mathrm{H}_{2}$ and between $17-\mathrm{H}$ and $19-\mathrm{H}_{3}$, indicating that the double bond between $\mathrm{C}-17$ and $\mathrm{C}-18$ is $\mathrm{Z}$ isomer.

\section{Biological Activities}

Insecticidal activity

Insecticidal activity of sesquicillins was studied against $A$. salina. Minimum growth inhibitory concentrations (MIC) are summarized in Table 4. Compound $\mathbf{1}$ showed the most
Table 4 Insecticidal and cytotoxic activities of $\mathbf{1}$ to $\mathbf{5}$

\begin{tabular}{ccc}
\hline Sesquicillin & $\begin{array}{c}\text { Insecticidal activity } \\
\text { MIC }(\mu \mathrm{g} / \mathrm{ml})\end{array}$ & $\begin{array}{c}\text { Cytotoxic activity }^{b} \\
I_{50}(\mu \mathrm{M})\end{array}$ \\
\hline A (1) & 6.25 & 34.0 \\
B (2) & $>200$ & $>100$ \\
C (3) & 100 & 38.3 \\
D (4) & $>200$ & $>100$ \\
E (5) & 100 & $>100$ \\
\hline
\end{tabular}

a) Growth inhibition against $A$. salina.

b) Growth inhibition against Jurkat cells.

potent with the MIC value of $6.25 \mu \mathrm{g} / \mathrm{ml}$, followed by 3 and 5 with $100 \mu \mathrm{g} / \mathrm{ml}$. However, 2 and $\mathbf{4}$ showed very weak inhibition at $200 \mu \mathrm{g} / \mathrm{ml}$.

\section{Antimicrobial Activity \\ Compounds $\mathbf{1}$ to $\mathbf{5}$ showed no antimicrobial activity against 14 microorganisms as described above at $10 \mu \mathrm{g} / 6 \mathrm{~mm}$ disk.}

\section{Cytotoxic Activity}

Cytotoxicity of $\mathbf{1}$ to $\mathbf{5}$ to Jurkat cells are summarized in Table 4. Compounds $\mathbf{1}$ and $\mathbf{3}$ showed cytotoxic with the $\mathrm{IC}_{50}$ value of 34.0 and $38.3 \mu \mathrm{g} / \mathrm{ml}$, respectively, while $\mathbf{2}, \mathbf{4}$ and 5 showed very weak cytotoxic activity at $100 \mu \mathrm{g} / \mathrm{ml}$.

\section{Discussion}

Five sesquicillin-related compounds including new ones $\mathbf{2}$ to $\mathbf{5}$ were isolated from the culture broth of Albophoma sp. FKI-1778. They have a common pyrano-diterpene moiety and a different isoprenoid side chain (Fig. 1). Sesquicillin A was reported to be produced by Sesquicillium and Acremonium. As described in this paper, however, the compound was also produced by a different genus Albophoma, which was originally reported as a new genus producing indoloditerpenes terpendoles, inhibiters of acylCoA: cholesterol acyltransferase [11,12]. It might be interesting to test whether these sesquicillin A-producing fungi produce structurally related terpendoles. In fact, we found that Albophoma sp. FKI-1778 produced terpendole C under the culture condition described above (data not shown). The detail about the relation between the fungi and the products will be reported.

Regarding the biosynthetic route, it was speculated that sescuicillin A (1) is first biosynthesized via coupling of a diterpene part (decalin) and a polyketide-derived pyranone part [13], then oxidized to give $\mathbf{3}, \mathbf{4}$ and $\mathbf{5}$ and finally to 
give 2 .

Regarding the biological activities of sesquicillins, a similar order of potency was observed in insecticidal and cytotoxic activities (Table 4); $\mathbf{1}$ is the most potent, followed by $\mathbf{3}$ and $\mathbf{5}$, and $\mathbf{2}$ and $\mathbf{4}$ show very weak activities. These results suggested that hydrophobic residues of the terminal isoprene moiety ( $\mathbf{R}$ in Fig. 1) are responsible for the biological activities.

Acknowledgements We are grateful to Ms. Akiko Nakagawa, Ms. Chikako Sakabe and Noriko Sato, School of Pharmaceutical Sciences, Kitasato University for measurements of mass and NMR spectra. This work was supported in part by the Grant of the 21st Century COE Program "Discovery of anti-infectious drugs from natural resources and its basic studies".

\section{References}

1. Ōmura S, Enomoto Y, Shinose M, Takahashi Y, Iwai Y, Shiomi K. Isolation and structure of a new antibiotic viridomycin F produced by Streptomyces sp. K96-0188. J Antibiot 52: 61-64 (1999)

2. Enomoto Y, Shiomi K, Matsumoto A, Takahashi Y, Iwai Y, Harder A, Kolbl H, Woodruff HB, Ōmura S. Isolation of a new antibiotic oligomycin G producesd by Streptomyces sp. WK-6150. J Antibiot 54: 308-313 (2001)

3. Shiomi K, Hatae K, Yamaguchi Y, Masuma R, Tomoda H, Kobayashi S, Ōmura S. New antibiotics miyakamides produced by a fungus. J Antibiot 55: 952-961 (2002)

4. Thiele B, Tscherter H. (Sandoz Ltd.) Verfahren zu
Herstellung eine neuen Metaboliten. DE 2,316,429, October 11th (1973)

5. Kuwabara A, Fujita S, Kobayashi S, Nishigori T. (Nippon Kayaku KK, Japan) Sesquicillin isomer manufacture with Acremonium. JP 8,092,119, April 9th (1996)

6. Engel B, Erkel G, Anke T, Sterner O. Sesquicillin, an inhibitor of glucocorticoid mediated signal transduction. J Antibiot 51: 518-521 (1998)

7. Jeong HW, Lee HJ, Kho YH, Son KH, Han MY, Lim JS, Lee MY, Han DC, Ha JH, Kwon BM. Biological effects of G1 phase arrest compound, sesquicillin in human breast cancer cell lines. Bioorg Med Chem 10: 3129-3134 (2002)

8. Jacobson E, Granville WC, Foss CE. Color Harmony Manual 4th Ed. Container of America, Chicago (1958)

9. Mosmann T. Rapid colorimetric assay for cellular growth and survival: application to proliferation and cytotoxicity assays. J Immunol Methods 16: 55-63 (1983)

10. Kobayashi T, Masuma R, Ōmura S, Watanabe K. Materials for the fungus flora of Japan (47). Mycoscience 35: 399-401 (1994)

11. Huang XH, Tomoda H, Nishida H, Masuma R, Ōmura S. Terpendoles, novel ACAT inhibitors produced by Albophoma yamanashiensis. I. Production, isolation and biological properties. J Antibiot 48: 1-4 (1995)

12. Huang XH, Nishida H, Tomoda H, Tabata N, Shiomi K, Yang DJ, Takayanagi H, Ōmura S. Terpendoles, novel ACAT inhibitors produced by Albophoma yamanashiensis. II. Structure elucidation of terpendoles A, B, C and D. J Antibiot 48: 5-11 (1995)

13. Kimura Y, T Hamasaki T, Suzuki A. Koen Yoshishu-Koryo Terupen oyobi Seiyu Kagaku ni kansuru Toronkai, 23rd, 288, 1979 